\title{
Suitability of the Iraqi natural clay for the preparation of Al-Fe pillared- clays
}

\author{
Faris Al-Ani ${ }^{1}$, Ghayda Al-Kindi, ${ }^{1, *}$ \\ ${ }^{1}$ Building and construction Engineering Department, University of Technology, Iraq
}

\begin{abstract}
Some organic pollutant in aqueous wastewater inhabitant biological treatment, catalyst wet air oxidation is a method to treat this waste. Al-Fe pillared Iraqi clays with different Fe content were prepared. Aluminum was mixed with iron in different molar ratio Fe/Al (1:9- 2:8- 3:7- 4-6- 5:5) for each regions. These clays collected from different location in Iraq (Anbar, Erbil, Mosel, Baghdad, and Basra), the results of some properties studied for natural and pillared clay, from X-RayFluorescence (XRF) show that iron cation replaces some $\mathrm{Ca}$ in the clay, and from X-Ray Diffraction (XRD) show the Calcite types of Iraqi clays. constructs clusters of active ingredient which dramatically clear on the catalytic surface for all catalyst types show through photos of catalysts by Scanning Electron Microscopy (SEM), the best molar ratio of $\mathrm{Fe} / \mathrm{Al}$ in which give strong interaction between $\mathrm{Fe}$ and $\mathrm{Al}$ in the pillared were (0.5-0.4-0.3-0.3 and 0.2) for (Mosul-Basra-Anbar-Baghdad and Erbil) respectively. This ratio gives high surface area, and pore size in mesopore. It is concluded that clay and silty clay (Mosul clay) consider the best catalyst due to higher activity and stability through experiment of $\mathrm{CWAO}$ in batch reactor, with operation condition $150^{\circ} \mathrm{C}, 2.5 \mathrm{Mpa}$, Ccat equal to $7 \mathrm{mg} / \mathrm{l}$.
\end{abstract}

\section{Introduction}

Pillared is one of the methods of clay modification, which have used the ion material in application of catalysts potential such as adsorption and separation processes [1]. That widespread delayed because in pilot scale difficulty obtaining a uniform and reproducible product because of several variables contribute to the preparation process and influence on the PILCs' properties [2]. The minerals clay properties tendency to improve the pillared such as, environmental compatibility, reusability and operational simplicity, low cost, high selectivity, porosity and stability of these materials [3], so that clay support catalyst exemplify of the largest group of catalysts (heterogeneous) which are important particularly in petroleum and petrochemical industries [4], as well as for its wastewater treatment.

The clay minerals structure, arrangement in two groups tetrahedrally and octahedrally in each group the atoms arranged in sheets and layers with the anion mainly $\mathrm{O}, \mathrm{OH}$, about the cations mainly $\mathrm{Mg}, \mathrm{Al}$, and $\mathrm{Fe}$ in Octahedral position and $\mathrm{Si}$, and $\mathrm{Al}$, in tetrahedral positions together in same minerals with interlayer cation $\mathrm{S}$ such as $\mathrm{K}, \mathrm{Na}, \mathrm{Ca}, \mathrm{Mg}$, The clays mostly used as catalysts are smectite, halloysite, sepiolite palygorskite and kaolin, [5]. The largest use of kaolin is in catalyst substrates in the catalytic cracking of petroleum [6], and in the synthesis of zeolites [7]. In addition, kaolin has been identified as a potential raw material for the production of alumina. The three layer stack clay structure know
Montmorillonite. The cation connection in the intervening by natural attraction and Vander Waal forces, this soil have exhibited high shrinkage and swelling characteristics when have a large amount of the mineral, [8] montmorillonite are complex layers of $\mathrm{SiO}_{2}$ and $\mathrm{ALO}_{4}$ tetrahedral, also containing small amount of $\mathrm{MgO}$ and $\mathrm{Fe}_{2} \mathrm{O}_{3}$ [9]. The most smectite minerals commonly used are Na-montmorillonite, $\mathrm{Ca}$ montmorillonite, saponite $(\mathrm{Mg})$, nontronite $(\mathrm{Fe})$, hectorite (Li) and beidellite (Al) [10]. Illite clay have Basic structure of this clay is the same as the one of montmorillonite. However, potassium ion $\left(\mathrm{K}^{+}\right)$are filled in between facing $\mathrm{O}^{2-}$ and $\mathrm{O}^{2-}$ surfaces of silica sheets. The clay characteristics are been classified between those of montmorillonite and kaolinite [11], these clays in granulated and powder form are the most important clay catalysts in the world. The small amount of active materials are added to surface of porosity solid support in the preparation of the solid catalyst, Most important of these oxides solids silica gel, $\mathrm{TiO}_{2}$, zeolite, alumina oxides, aluminum silicates, activated carbon, $\mathrm{ZrO}_{2}, \mathrm{MgO}$, and ceramics [12]. The classical pillaring method includes two steps, physical and chemical. In physical stage swelling in clay and exchange of the interlayer cations by partially hydrated polymeric, but in second step thermal treatment of the intercalated clay mineral.

Some attempts were successful in preparing large pore in pillared clays using rare element /aluminum. The ratio of $\mathrm{OH} / \mathrm{Al}$ in the pillaring solution was a

\footnotetext{
*Corresponding author: alkindi.ghydaa@gmail.com
} 
controlling factor of increasing basal spacing [13]. While calcing was a controlling factor on surface area, various types of solids have been employed to catalyst for oxidation of organic compounds in wastewaters: transition-metal and noble metals, the noble metals have been extensively used as active components [14]. Fe used in prepared pillared clay due to high oxidation state and high stability [15], the advantage of used combined two or more metal oxide catalysts, which can improved selectivity, catalytic activity and increasing the rate of the processes [16]. Such as increase thermal stability and catalytic properties when used $\mathrm{Fe}$ as second cation with Al-pillared clays [17], To increase the efficiency of process of wet oxidation, which has been modified or has been used a suitable combination of processes [16].

The goal of this study is to prepare AL-Fe pillared Iraqi clay to be used in removal of some pollutants of wastewater. The clays were collected from five regions. Which have different type of clays. Anbar (from west 40Km from H3), Mosul (from north Smehlla Quarries 36 $31^{\prime} 25 \mathrm{~N}, 4^{\circ} 53^{\prime} 52 \mathrm{E}$ ), Baghdad (from central Quarries brick factory Mohamed Adnan in AL Nahrawan $33^{\circ} 24^{\prime} 6 \mathrm{~N}, 4^{\circ} 51^{\prime} 0 \mathrm{E}$ ), and Basra (from south brick factory for $\mathrm{Abu} \mathrm{AL}$ Khaseeb E:782004, N:3373832 from Shatt Al-Arab) Collected to represent the topography of all Iraq, and only those available at the General Authority for Geological Survey, in addition to the samples collected from Erbil in the Kurdistan Iraq from Khlefan mountains, to choose the best catalyst depending on surface area, pore size, activity and stability for removal phenol and TOC from synthetic wastewater by CWO.

\section{Experimental work}

\subsection{Selecting the best condition}

In the beginning, according to XRD test Anbar soil was selected to find the best conditions as calcing temperature, and molar ratio $\mathrm{OH} /(\mathrm{Al}+\mathrm{Fe})$, the scheme diagram which is used to find the stable operation condition show in Figure (1).

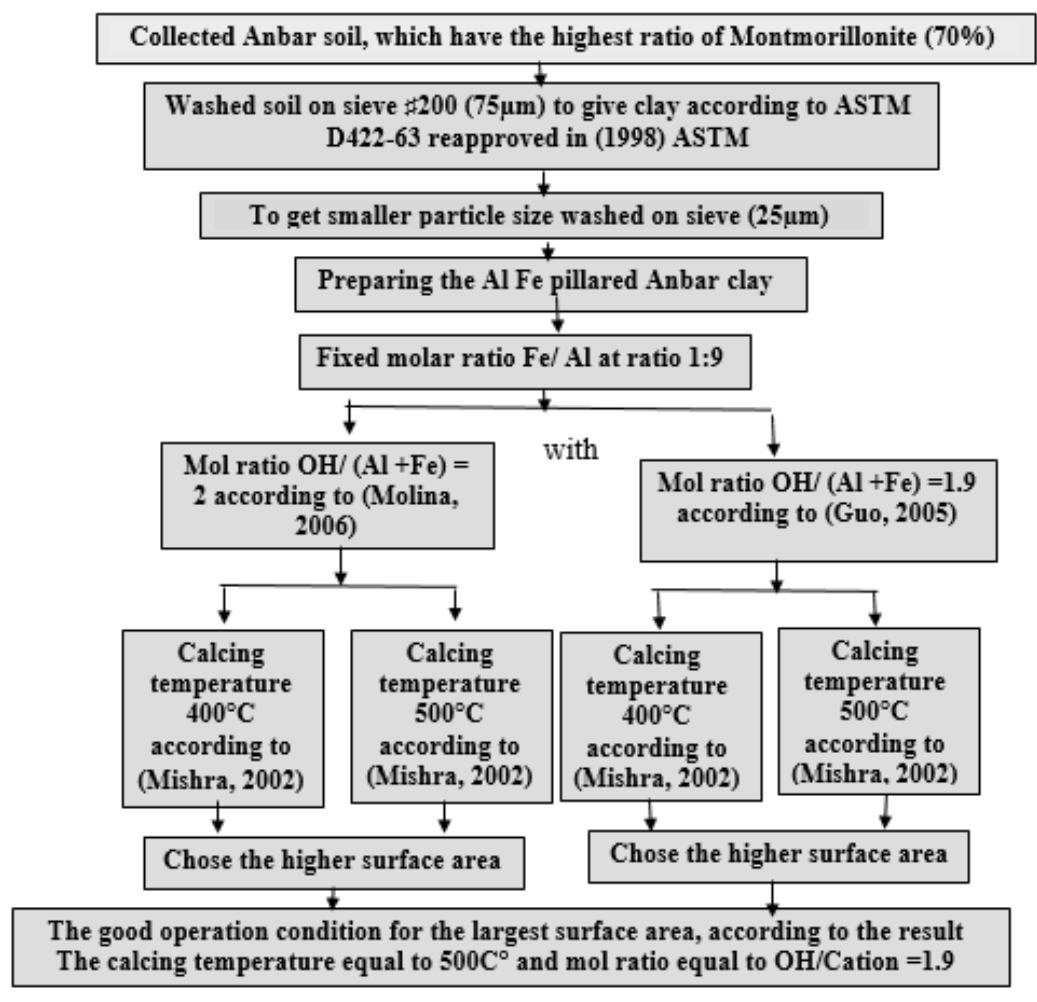

Fig. 1. Scheme diagram to find the operation condition for preparing pillared clays [18].

\subsection{Preparation of pillared clay}

From collected stack soil the preparation has done according to Professor N. Papayannakos process (Analysis and Plant Design Group at National
Technical University of Athens, NTUA) as prepared by Guo, 2005 [17]. Figure (2) shows schematic representation of the conventional process of preparation pillared clay. 


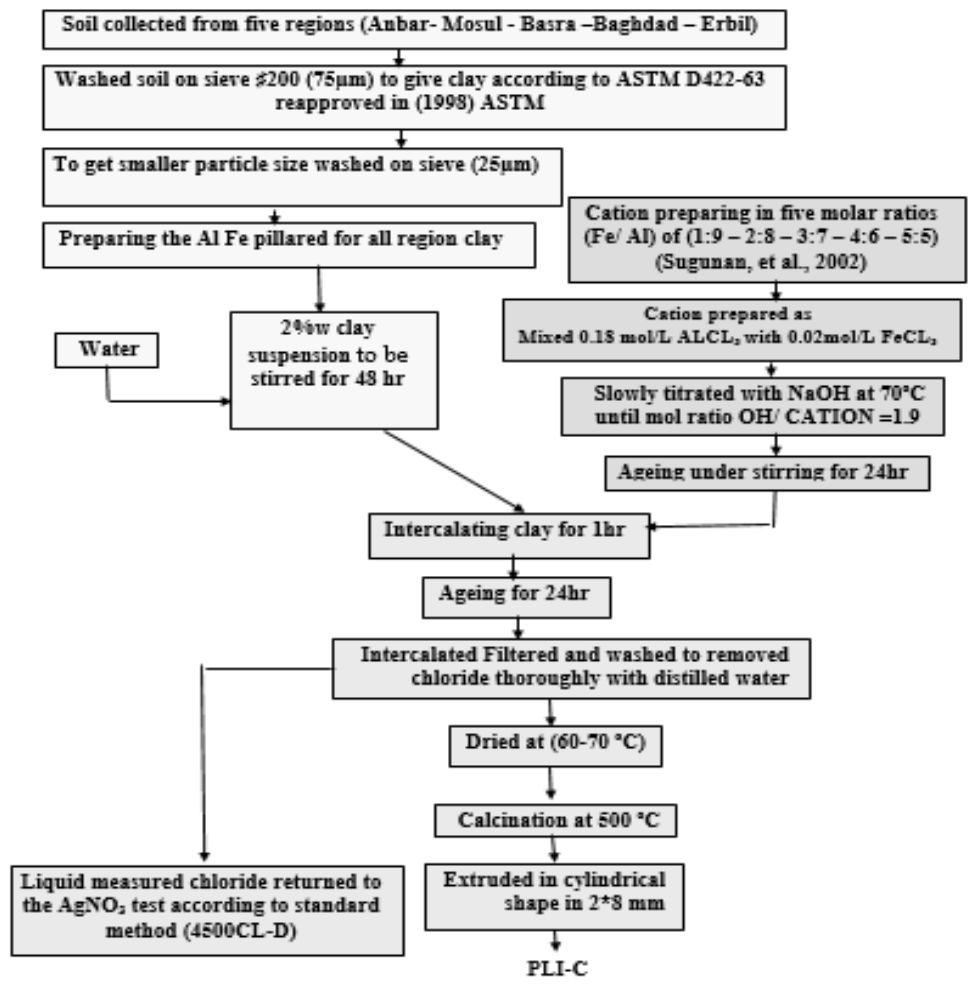

Fig. 2. Schematic representation of the conventional process of pillared clay [19]

Many tests required to study the characterization of soil and pillared clay many tests were done such as hydrometer test, Blumenauer-Emmer-Teller (BET), Xray Diffraction XRD, X-ray florescent (XRF), Scanning Electron Microscope (SEM).

\subsection{Activity measurement}

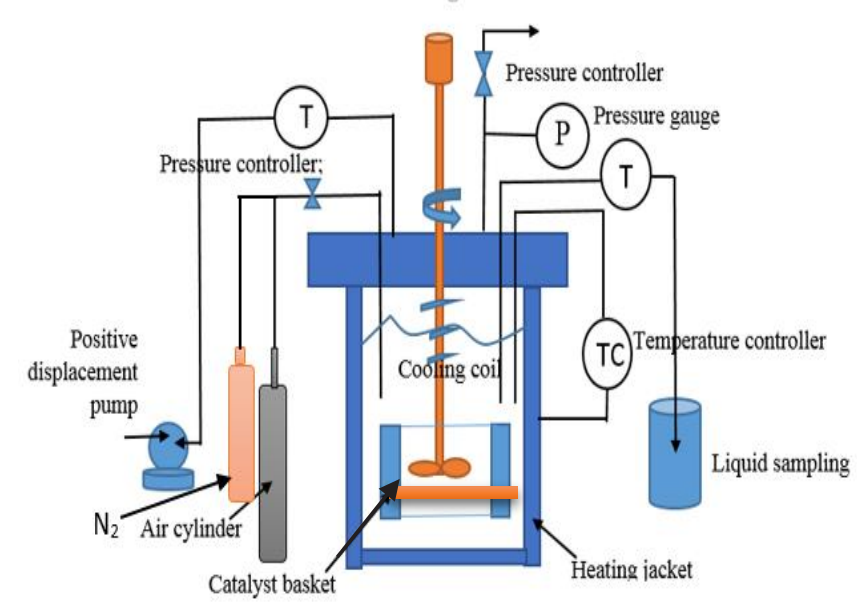

Fig. 3. Diagram of the experimental setup.

The 500mg of phenol has been diluted with distilled water, add sulfuric acid $(1 \mathrm{~N})$ to reach $\mathrm{pH} 3.9-4$, putting in $600 \mathrm{ml}$ Vessel. For each catalyst region, and putting in a basket inside the reactor, the rotation speed was kept at $800 \mathrm{rpm}$. Nitrogen pressured to $1 \mathrm{Mpa}$ to inert the reactor, purified air $(21 \%$ pure oxygen mixed with $79 \%$ pure nitrogen) was continuously fed into the
From the result of previous experimental test, the maximum operating condition are temperature and pressure of $500 \mathrm{C}^{\circ}-5 \mathrm{MPa}$ respectively, in Basket Stirred Batch Reactor (BSBR), made from stainless steel designed for experimental work. The experimental scheme is depicted in Figure (3). 
(nylon filter) $0.2 \mu \mathrm{m}$ pore size. The samples were stored in the freezer to the time of test in order to stop the reaction [17].

The air was manually set to the required partial pressure for the duration of the experiment. The airflow rate was maintained constant [9]. Every batch was washed to remove all fines, then dried overnight prior to other use.

The filtered samples were analyzed by Germany High Performance Liquid Chromatography (HPLC) YL 9100 HPLC System, YL 9101 Vacuum Degasser. And YL 9110 Quaternary pump, YL 9120 UV/Vis Detector with C18 column. A mobile phase $\mathrm{H}_{2} \mathrm{SO}_{4}$ of variable composition was programmed at a $1.2 \mathrm{ml} / \mathrm{min}$ flow rate. The wave length between 450 $550 \lambda$ detected phenol and low molecular weight Intermediates compound. The (UV -VV-1100, UEBO9025) Spectrophotometer was used to detect phenol concentration. The total organic carbon (TOC) has been measured by Shimadzu TOC-LCSH/CSN Standalone Model TOC analyzer. Leaching Fe concentration in the wastewater from reaction media was also analyzed by Atomic Absorption.

\section{Result and Discussion}

Hydrometer tests of fine-grained soils, (silts and clays), which gives the particle size distribution for the Iraqi`s soil collected from five areas. The hydrometer test result, for Basra refer to sand, silt, and clay in varying percentages of $50 \%$ silt, $30 \%$ clay, and $20 \%$ sand while, Baghdad, Mosul proved it is a clay (60\%) and silt (40\%) approximately. Anbar and Erbil did not give any result because swelling occurred as shown in Figure (4).

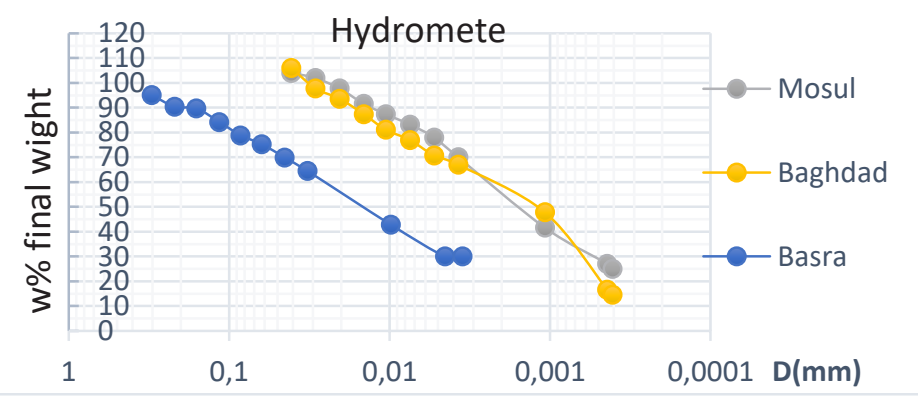

Fig. (4): Hydrometer of collected Iraqi soil

(XRD) X-ray diffraction is a technique used to research about characteristics of crystalline structure and to study the mineralogy of finer grained clays [20]. According to X-ray diffraction patterns, the following phases were identified in the investigated catalyst samples according to (standard powder diffraction data 1990) [21], typical XRD patterns of Al-Fe clay before and after pillaring with mixed $\mathrm{Fe}$ and $\mathrm{Al}$ polyoxocation (Fe-Al-CTE). The d (001) peak for the ordinary clay corresponds to a 3.0202, 3.02516, 3.0400, 3.03019,

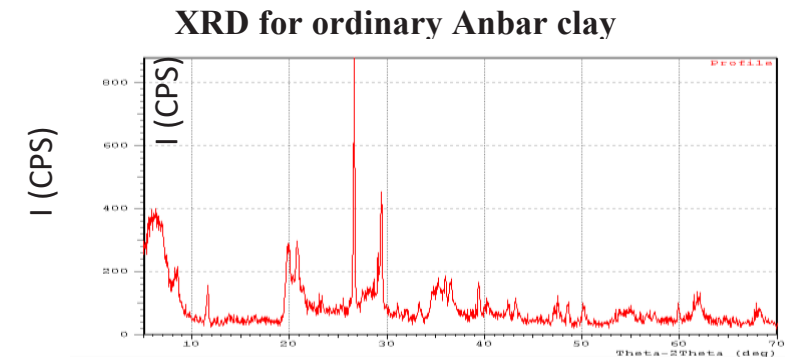

XRD for ordinary Mosul clay
3.02524 Å for Anbar- Mosul- Baghdad- Basra- Erbil clays respectively, spacing, and is increased to $\mathrm{d}(001)$ spacing of 3.03165, 3.3286, 3.30064, 3.33455, 3.33879 $\AA$, for Anbar- Mosul- Baghdad- Basra- Erbil clays respectively, which indicates the extent of the pillaring process. Also show the Iraqi clays are calsumy have two layers of silica and one layer of alumina this conforming to result of Aibert, 1980 [22].The result of this test is shown in Figure (5)

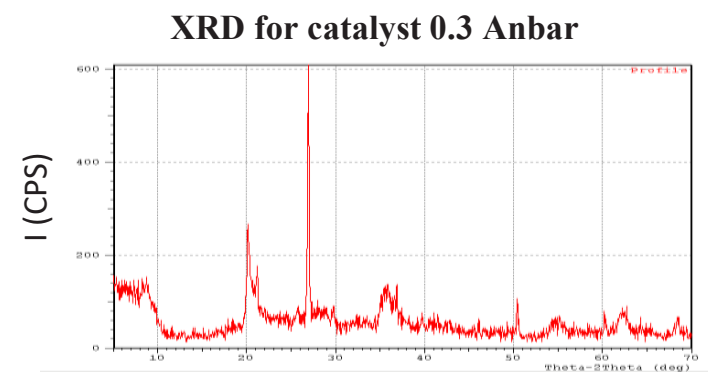

XRD for catalyst 0.5 Mosul 


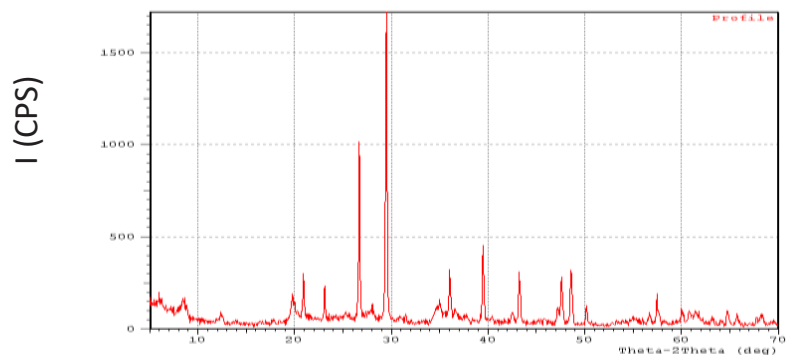

XRD for ordinary Baghdad clay

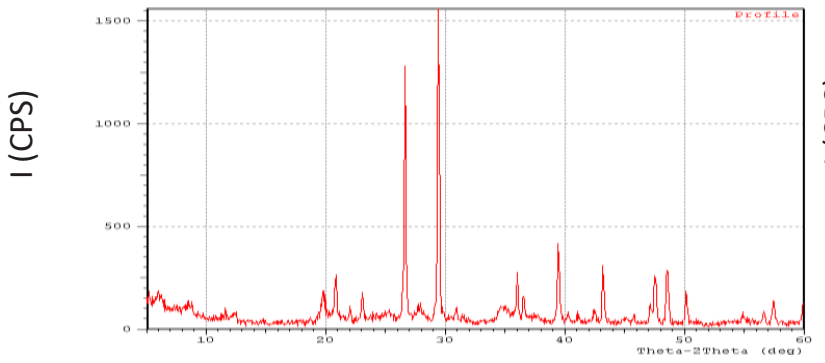

XRD for ordinary Basra clay

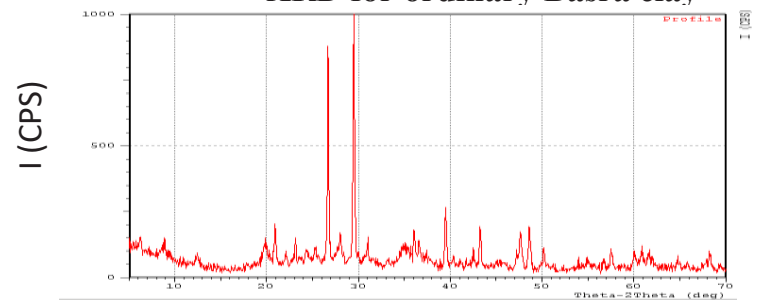

XRD for ordinary Erbil clay

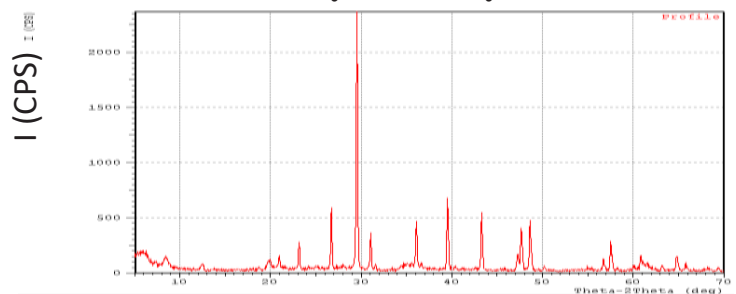

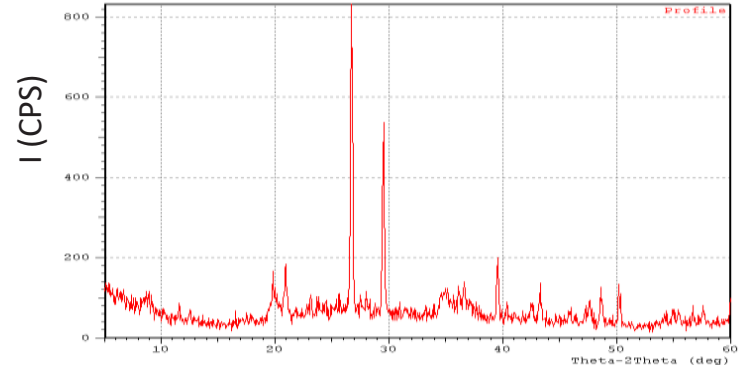

XRD for catalyst 0.3 Baghdad

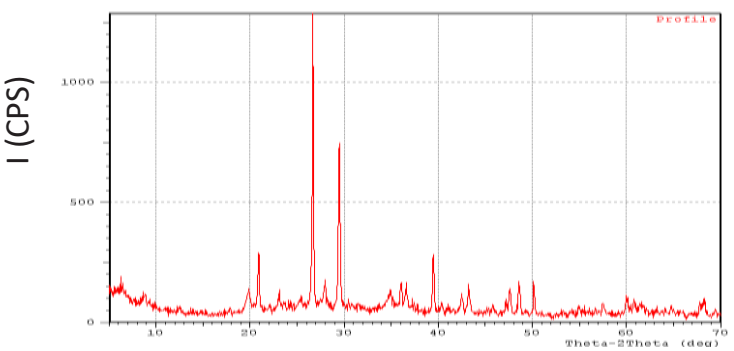

XRD for catalyst 0.4 Basra

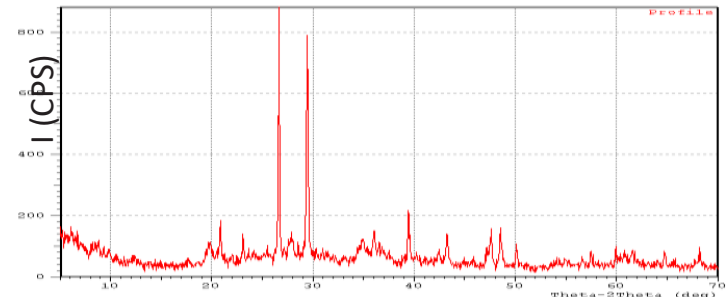

XRD for catalyst 0.2 Erbil

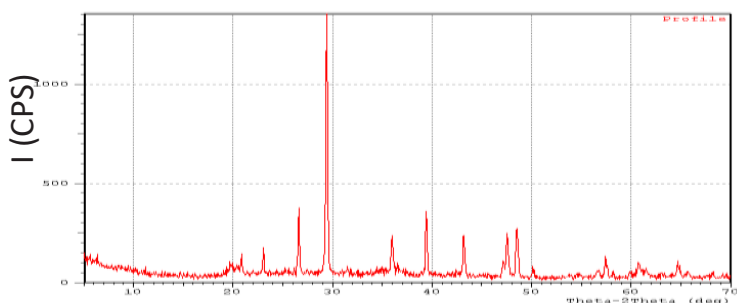

Fig. (5): XRD result for ordinary and Al -Fe pillared clay for Erbil, Mosul, Anbar, Baghdad, Basra

The results of XRF analyses for ordinary clay and $\mathrm{Al}$ Fe pillared clays (catalyst) indicate that ratio of the $\mathrm{Fe}_{2} \mathrm{O}_{3} \%$ and $\mathrm{Al}_{2} \mathrm{O}_{3} \%$ in pillared clay is higher than ordinary clay, Baghdad clay shows increase in $\mathrm{Al}_{2} \mathrm{O}_{3}$ $\%$ than other pillared clay, followed by Basra, Erbil,
Anbar, and Mosel, but the ratio of calcium oxide in all pillared clay degrease in ratio than ordinary clay due to exchange between cation and $\mathrm{Ca}$. Also the ratio of $\mathrm{Si}_{2} \mathrm{O}_{3}$ has degrease, these result shown in Table (1).

Table 1: main composition of the ordinary and catalys

\begin{tabular}{|c|c|c|c|c|c|c|c|c|c|c|}
\hline Ratio & $\begin{array}{c}\text { Anbar } \\
\text { Ordinary } \\
\text { clay }\end{array}$ & $\begin{array}{c}\text { Anbar } \\
\text { catalyst }\end{array}$ & $\begin{array}{c}\text { Mosul } \\
\text { Ordinary } \\
\text { clay }\end{array}$ & $\begin{array}{l}\text { Mosul } \\
\text { catalyst }\end{array}$ & $\begin{array}{l}\text { Baghdad } \\
\text { Ordinary } \\
\text { clay }\end{array}$ & $\begin{array}{l}\text { Baghdad } \\
\text { catalyst }\end{array}$ & $\begin{array}{c}\text { Basra } \\
\text { Ordinary } \\
\text { clay }\end{array}$ & $\begin{array}{c}\text { Basra } \\
\text { catalyst }\end{array}$ & $\begin{array}{c}\text { Erbil } \\
\text { Ordinary } \\
\text { clay }\end{array}$ & $\begin{array}{c}\text { Erbil } \\
\text { catalyst }\end{array}$ \\
\hline $\mathrm{SiO}_{2} \%$ & 23.75 & 20.26 & 36.38 & 32.35 & 41.38 & 39.04 & 34.18 & 28.7 & 57 & 55.36 \\
\hline $\mathrm{Fe}_{2} \mathrm{O}_{3 \%}$ & 3.93 & 7.98 & 5.42 & 9.82 & 5.2 & 7.8 & 6.2 & 14.81 & 5.5 & 9.6 \\
\hline $\mathrm{AL}_{2} \mathrm{O}_{3 \%}$ & 5.82 & 15.37 & 9.64 & 14.35 & 9.76 & 29.49 & 9.77 & 21.73 & 13.5 & 23.4 \\
\hline
\end{tabular}


The Blumenauer-Emmer-Teller (BET) Method give description and more explanation of surface area for each region according to above conditions shown in Tables (2 to 6). The final result of surface area of catalyst for all types which was significantly higher than ordinary clay, showns in Table (7). The results of experimental works show that the best ratio used in preparing the pillared clay were $(0.3,0.5,0.3,0.4$, and 0.2) for (Anbar, Mosul, Baghdad, Basra, and Erbil), respectively. These ratios were selected depending on result of surface area. And these results of surface area are in agreement with results obtained by Bankovic, 2009 [23]. The constructing an adsorption isotherm in Figure (6) contributed an understanding of the pore size and surface area of a porous media. That figure represents the typical nitrogen adsorption isotherm obtained for the Al-Fe pillared Iraqi clay catalyst. The linear portion of the adsorption curve in the $\mathrm{P} / \mathrm{P}_{0}$ (relative pressure, correlated to the amount of adsorbed nitrogen) show the range between 0.04-0.3

Table (2) show result of BET surface area of Anbar Traphawy at $500 \mathrm{C}^{\circ}$ for $1 \mathrm{~h}$

\begin{tabular}{|c|c|c|}
\hline samples & $\begin{array}{c}\text { Surface area } \\
\mathbf{m}^{2} / \mathbf{g m}\end{array}$ & $\begin{array}{c}\text { Pore volume } \\
\mathbf{c m}^{3} / \mathbf{g m}(\AA)\end{array}$ \\
\hline Stack clay & 75.2158 & $\mathbf{0 . 0 8 6 3 5}$ \\
\hline pillared 0.1 & $\mathbf{9 2 . 1 5 1 8}$ & $\mathbf{0 . 0 8 1 9 8}$ \\
\hline pillared 0.2 & $\mathbf{8 8 . 1 7 3 4}$ & $\mathbf{0 . 0 5 0 8}$ \\
\hline pillared 0.3 & 97.8157 & $\mathbf{0 . 0 9 6 2}$ \\
\hline pillared 0.4 & $\mathbf{7 3 . 8 3 6 3}$ & $\mathbf{0 . 0 6 1 1}$ \\
\hline pillared 0.5 & $\mathbf{6 3 . 6 5 0 7}$ & $\mathbf{0 . 0 6 0 7}$ \\
\hline
\end{tabular}

Table (4) show result of BET surface area Basra Abu AL-Khaseeb at $500 \mathrm{C}^{\circ}$ for $1 \mathrm{hr}$

\begin{tabular}{|c|c|c|}
\hline samples & $\begin{array}{c}\text { Surface area } \\
\mathbf{m}^{2} / \mathbf{g m}\end{array}$ & $\begin{array}{c}\text { Pore } \\
\text { volume } \\
\mathbf{c m}^{3} / \mathbf{g m}(\AA)\end{array}$ \\
\hline Stack clay & 41.475 & 0.05325 \\
\hline pillared 0.1 & 42.235 & $\mathbf{0 . 0 7 4 6}$ \\
\hline pillared 0.2 & 53.317 & $\mathbf{0 . 0 8 9 4}$ \\
\hline pillared 0.3 & 56.973 & $\mathbf{0 . 0 9 0 7}$ \\
\hline pillared 0.4 & 49.1577 & $\mathbf{0 . 8 3 8 5}$ \\
\hline pillared 0.5 & 54.5577 & $\mathbf{0 . 7 9 2 1}$ \\
\hline
\end{tabular}

Table (6) show result of BET surface area Erbil Khleaphan at $500 \mathrm{C}^{\circ}$ for $1 \mathrm{hr}$

\begin{tabular}{|c|c|c|}
\hline samples & $\begin{array}{c}\text { Surface } \\
\text { area } \mathbf{~ m}^{2} / \mathbf{g m}\end{array}$ & $\begin{array}{c}\text { Pore volume } \\
\mathbf{c m}^{3} / \mathbf{g m}(\AA)\end{array}$ \\
\hline Stack clay & 47.57 & 0.06236 \\
\hline pillared 0.1 & 85.527 & 0.1201 \\
\hline pillared 0.2 & 100.742 & 0.1221 \\
\hline
\end{tabular}

The pore size being at upper mesoporous, but from 0.3 0.99 the pore size being at the low macropore range as reference by Gregg and Sing, 1983 [24], The Al -Fe pillared Iraqi clay for five regions range between (0.04$0.3)$ that can be considered mesopore, after this value (0.3-0.99) it is small macropore as reference by Gregg and Sing, $1983^{(24)}$. Also the pores size is characteristic of mesopore according to the International Union of Pure and Applied Chemistry (IUPAC) classification of pore size $(\AA)$ as macropore ( $\geq 500)$, mesopore (20 to $500)$ supermicropore (7-20) and ultramicropore $(\leq 7)$ [25]. From the results Baghdad have the highest value of pore size width $150.4 \AA$, but Basra have lowest value $75.1 \AA$, all regions are mesopore size so that all pillared suitable to be catalyst as reference by Lastoskie, 1993 [26].

Regarding pore volume which depends on the type of clay and calcing, Mosul has the largest pores volumes, followed Erbil, Basra, Anbar, and Baghdad, where the major part of the surface area contributed by pores, where internal chemical reaction gates.

Table (3) show result of BET surface area of at $\mathrm{AL}$ Mosul Smahalla $500 \mathrm{C}^{\circ}$ for $1 \mathrm{hr}$

\begin{tabular}{|c|c|c|}
\hline samples & $\begin{array}{c}\text { Surface area } \\
\mathbf{m}^{\mathbf{2}} / \mathbf{g m}\end{array}$ & $\begin{array}{c}\text { Pore volume } \\
\mathbf{c m}^{\mathbf{3}} / \mathbf{g m}(\mathbf{\AA})\end{array}$ \\
\hline Stack clay & 78.8355 & 0.0911 \\
\hline pillared 0.1 & 55.2218 & 0.0999 \\
\hline pillared 0.2 & 80.9344 & 0.1320 \\
\hline pillared 0.3 & 63.3475 & 0.0989 \\
\hline pillared 0.4 & 74.9119 & 0.1214 \\
\hline pillared 0.5 & 93.6052 & 0.1430 \\
\hline
\end{tabular}

Table (5) show result of BET surface area of of Baghdad AL Nahrawan at $500 \mathrm{C}^{\circ}$ for $1 \mathrm{hr}$

\begin{tabular}{|c|c|c|}
\hline samples & $\begin{array}{c}\text { Surface area } \\
\mathbf{m}^{2} / \mathbf{g m}\end{array}$ & $\begin{array}{c}\text { Pore volume } \\
\mathbf{c m}^{3} / \mathbf{g m}(\AA)\end{array}$ \\
\hline Stack clay & 51.117 & 0.084 \\
\hline pillared 0.1 & 47.00 & 0.108 \\
\hline pillared 0.2 & 43.28 & 0.096 \\
\hline pillared 0.3 & 46.45 & 0.098 \\
\hline pillared 0.4 & 61.3711 & 0.1109 \\
\hline pillared 0.5 & 60.28 & 0.101 \\
\hline
\end{tabular}

Table 7: physical properties of various catalyst sample

\begin{tabular}{|c|c|c|c|c|}
\hline $\begin{array}{c}\text { Samples } \\
\text { Region }\end{array}$ & $\begin{array}{c}\text { Ratio } \\
\text { Fe/(AL+Fe) } \\
\text { Used to } \\
\text { prepare AL-Fe } \\
\text { pillars clay }\end{array}$ & $\begin{array}{c}\text { (BET) } \\
\text { Surface } \\
\text { area } \\
\mathbf{m}^{2} / \mathbf{g}\end{array}$ & $\begin{array}{c}\text { Average } \\
\text { Pore volume } \\
\mathbf{m}^{3} / \mathrm{g}\end{array}$ & $\begin{array}{c}\text { Pore } \\
\text { size } \\
\text { width } \\
\AA\end{array}$ \\
\hline $\begin{array}{c}\text { Anbar } \\
\text { CLAY }\end{array}$ & & 75.215 & $\mathbf{0 . 0 8 6 3 5}$ & \\
\hline $\begin{array}{c}\text { Anbar } \\
\text { Catalyst }\end{array}$ & $\mathbf{0 . 3}$ & 97.815 & $\mathbf{0 . 0 9 6 2}$ & 78.4 \\
\hline Erbil CLAY & & 47.57 & $\mathbf{0 . 0 6 2 3 6}$ & \\
\hline
\end{tabular}




\begin{tabular}{|c|c|c|}
\hline pillared 0.3 & 99.412 & 0.1332 \\
\hline pillared 0.4 & 96.6770 & 0.1242 \\
\hline pillared 0.5 & 99.3033 & 0.0131 \\
\hline
\end{tabular}

Nitrogen adsorption isotherm

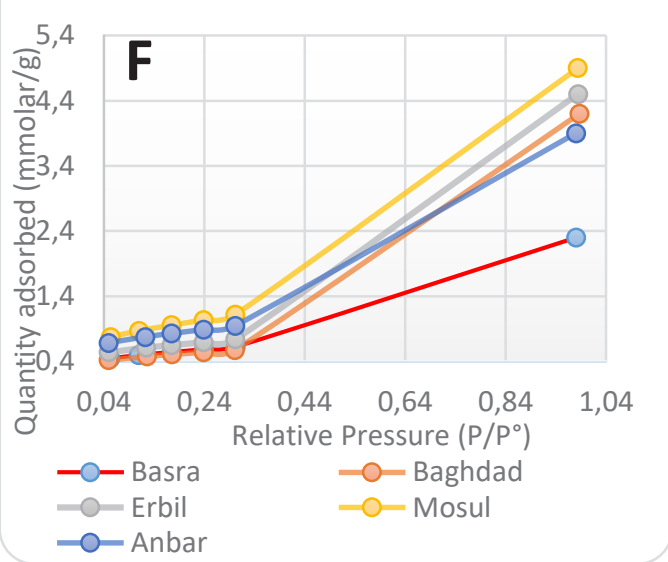

Fig.6: Nitrogen adsorption isotherms liner plot for Fresh Al-Fe pillared Iraqi clay for (a) Anbar (b) Erbil (c) Mosul (d) Baghdad (e) Basra

To understand the morphology of ordinary clay and catalyst visualization of surface reaction scanning electron microscopy was used as shown in Figure (7) which give the image of ordinary clay and

\begin{tabular}{|c|c|c|c|c|}
\hline $\begin{array}{c}\text { Erbil } \\
\text { Catalyst }\end{array}$ & 0.2 & 100.74 & 0.1221 & 124.2 \\
\hline $\begin{array}{c}\text { Baghdad } \\
\text { CLAY }\end{array}$ & & 41.475 & 0.05325 & \\
\hline $\begin{array}{c}\text { Baghdad } \\
\text { Catalyst }\end{array}$ & 0.3 & 56.973 & 0.0907 & 150.4 \\
\hline $\begin{array}{c}\text { Mosul } \\
\text { CLAY }\end{array}$ & 0.5 & 78.835 & 0.0911 & \\
\hline $\begin{array}{c}\text { Mosul } \\
\text { Catalyst }\end{array}$ & 93.605 & 0.1430 & 89.7 \\
\hline $\begin{array}{c}\text { Basra } \\
\text { CLAY }\end{array}$ & 0.4 & 51.117 & 0.084 & \\
\hline $\begin{array}{c}\text { Basra } \\
\text { Catalyst }\end{array}$ & & 61.371 & 0.1109 & 75.1 \\
\hline
\end{tabular}

catalyst, these figures show the pores and surface roughness in different magnification and show boundary of crystals regions on the catalyst image described in a circle around it.

\section{Clay Anbar}

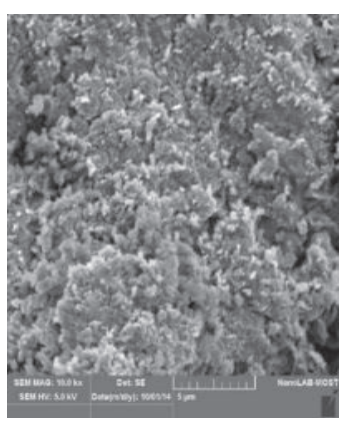

\section{Catalyst Baghdad 0.3}

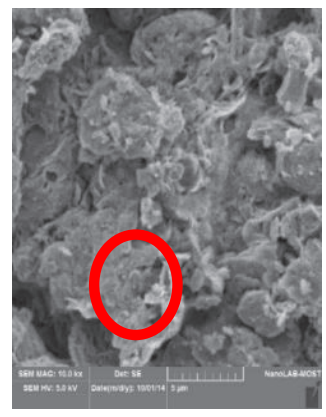

Catalyst Anbar 0.3

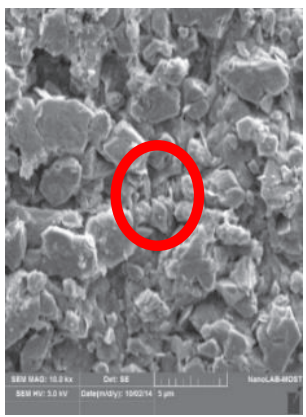

clay Basra

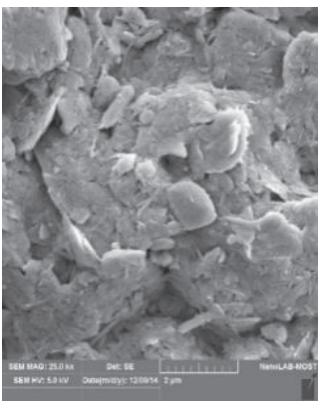

Clay Mosul

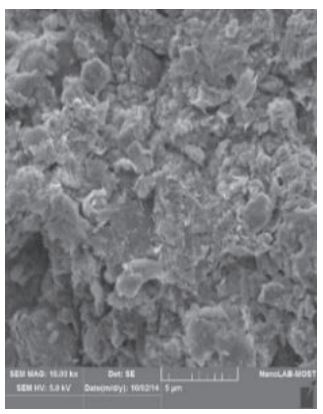

Catalyst Basra

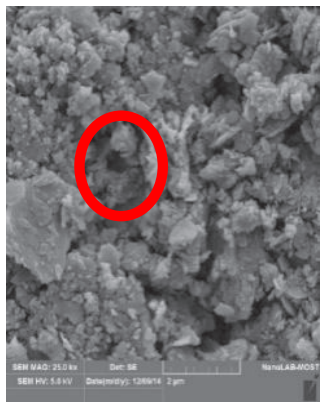

\section{Catalyst Mosul 0.5 Clay Baghdad}
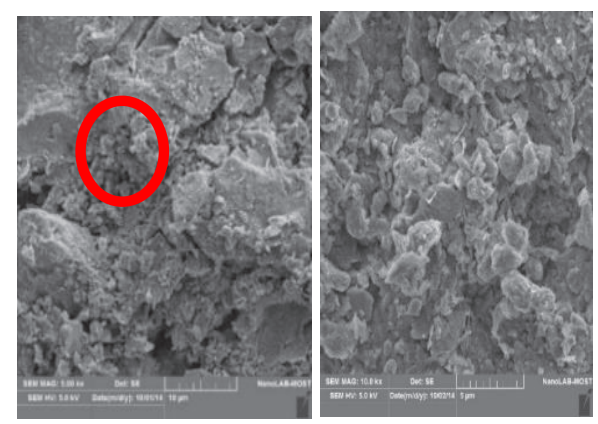

clay Erbil

Catalyst Erbil 0.2
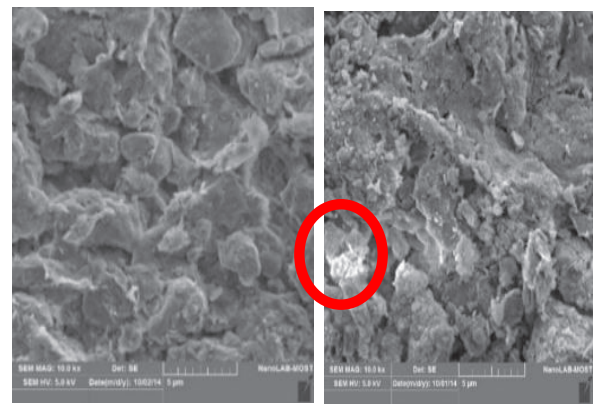

Fig. 7: SEM images of Fresh Al-Fe pillared clay catalyst with magnification of ( $5 \mu \mathrm{m}$ scale) crystals marked by circle

\subsection{Chemical properties of clay catalyst}

From the results of experimental works, the $\mathrm{pH}$ increases in catalyst than clay due to $\mathrm{AlOH}_{3}$ and 
$\mathrm{FeOH}_{3}$ obtained from the reaction of hydroxide with $\mathrm{FeCl}_{3}$ and $\mathrm{AlCl}_{3}$ and remained after calcing. The value of chloride in catalyst is less than that in clay because of washing during preparing. The needle shape sulfate in catalyst is considered impurity. If the sulfate ratio was between $1-2 \%$ that important to solid catalyst due to increase in acidity, and causes deactivation when the sulfate contain in catalyst $>3 \%$ as stated by McNaught et al., (2006) [27]. The value of sulfate concentration in catalyst was reduced but still $>3 \%$ so that it reasoned of deactivation. Carbonation causes the problems due to its low solubility in water and increases the cohesion of clay, which reduces the surface area, in this study the carbonation concentration was reduced slightly after preparing the catalyst, but considered high due to the natural Iraqi clay which have a high amount of sulfate and carbonite, these results shown in Table (8) (for stack clay) and in Table (9) (for catalyst).

Table (8): Measuring the percentage of ions in clay

\begin{tabular}{|c|c|c|c|c|c|}
\hline \multicolumn{6}{|c|}{ Measuring of Catalyst } \\
\hline test & Anbar & Erbil & Mosul & Baghdad & Basra \\
\hline pH & 9.81 & 9.53 & 9.82 & 9.39 & 9.22 \\
\hline EC mv/cm & 166.3 & 149.3 & 165.4 & 141.6 & 130.9 \\
\hline $\mathrm{CL}^{-} \%$ & 0.007 & 0.056 & 0.015 & 0.039 & 0.097 \\
\hline $\mathrm{SO}_{3}^{-} \%$ & 2.058 & 2.06 & 6.86 & 3.43 & 3.43 \\
\hline $\mathrm{SO}_{4}^{-\%} \%$ & 4.424 & 4.425 & 14.75 & 7.37 & 7.37 \\
\hline $\mathrm{CO}_{3}^{-} \%$ & 0.63 & 0.73 & 0.68 & 0.61 & 0.69 \\
\hline TSS \% & 0.006 & 0.0067 & 0.006 & 0.007 & 0.0076 \\
\hline $\mathbf{T} \mathbf{C}^{\circ}$ & 25 & 25 & 25 & 25 & 25 \\
\hline
\end{tabular}

Table (9): Measuring the concentration of ion and salt in catalyst

\begin{tabular}{|c|c|c|c|c|c|}
\hline \multicolumn{7}{|c|}{ Measuring of CLAY } \\
\hline test & Anbar & Erbil & Mosul & Baghdad & Basra \\
\hline pH & 7.98 & 8.82 & 8.55 & 8.35 & 8.54 \\
\hline EC mv/cm & 57.7 & 107.7 & 91.7 & 79.5 & 90.7 \\
\hline CL $^{-~ \% ~}$ & 0.74 & 0.055 & 0.143 & 0.264 & 0.172 \\
\hline SO $^{-} \%$ & 6.86 & 13.7 & 13.6 & 13 & 20.58 \\
\hline SO $_{4}^{-\%}$ & 14.75 & 29.46 & 29.24 & 27.95 & 44.25 \\
\hline CO $_{3}^{-} \%$ & 0.65 & 0.6 & 0.65 & 0.72 & 0.65 \\
\hline TSS $\%^{\text {T C }}$ & 0.0173 & 0.093 & 0.012 & 0.013 & 0.011 \\
\hline & 25 & 25 & 25 & 25 & 25 \\
\hline
\end{tabular}

The activity of the heterogeneous catalytic system was also studied for all catalyst regions in stirred basket batch reactor, at different temperatures between $\left(90-150{ }^{\circ} \mathrm{C}\right)$, while the constant for other parameter pressure $2.5 \mathrm{MPA}$, catalyst loading $\mathrm{C}_{\text {Cat }}$ equal to $7 \mathrm{mg} / 1$. Figures (8) shows phenol concentration at different temperatures for different catalyst regions. Figures (9) shows phenol conversion profiles of reactions performed at temperatures $90,110,130$ and $150 \mathrm{C}$, the result phenol conversion 96.2, 95.44, 93.7, 80, 76.3\% for Erbil, Mosul, Anbar, Baghdad, Basra, respectively. The temperature at $150^{\circ} \mathrm{C}$ is necessary to obtain phenol conversion along the process because mass transfer of oxygen from the gas phase to the liquid phase is required. Also the temperature between (100$150 \mathrm{C}$ ) is considered ideal for most of catalyst so that the activated energy increase with increase temperature reach to $50 \mathrm{kj} / \mathrm{molar}$ than increase $1^{\circ} \mathrm{C}$ in temperature increase activated energy $10 \mathrm{kj} / \mathrm{molar}$ therefore causing double conversion rate lead to disequilibrium state [28]. The reaction rate is increasing gradually with time especially at a temperature of $150^{\circ} \mathrm{C}$. Erbil has the highest value of phenol degradation rate and followed by Mosul, Anbar, Baghdad and Basra respectively. This is expected in some catalyst types which reached to complete minimization $\left(\mathrm{H}_{2} \mathrm{O}\right.$ and $\mathrm{CO}_{2}$ ), because in the first step of phenol oxidation corresponds to the formation organic acid and in further oxidation reach to $\mathrm{H}_{2} \mathrm{O}$ and $\mathrm{CO}_{2}$ [29]. Figure (10) shows TOC concentration at different temperatures for different catalyst regions. Figures (11) shows TOC conversion, the higher TOC conversion for Anbar catalyst reach to $88 \%$ than Erbil $79.28 \%$, Mosul $78.2 \%$, Baghdad $66.5 \%$ and Basra $66.46 \%$. The deactivation appears on the surface of pillared Anbar and Erbil clay. The pathway reaction for all sample catalysts were shown in first step phenol oxidation the benzoquinone formation in some samples while other have Malic acid, were in subsequent period all samples formation acetic acid. 


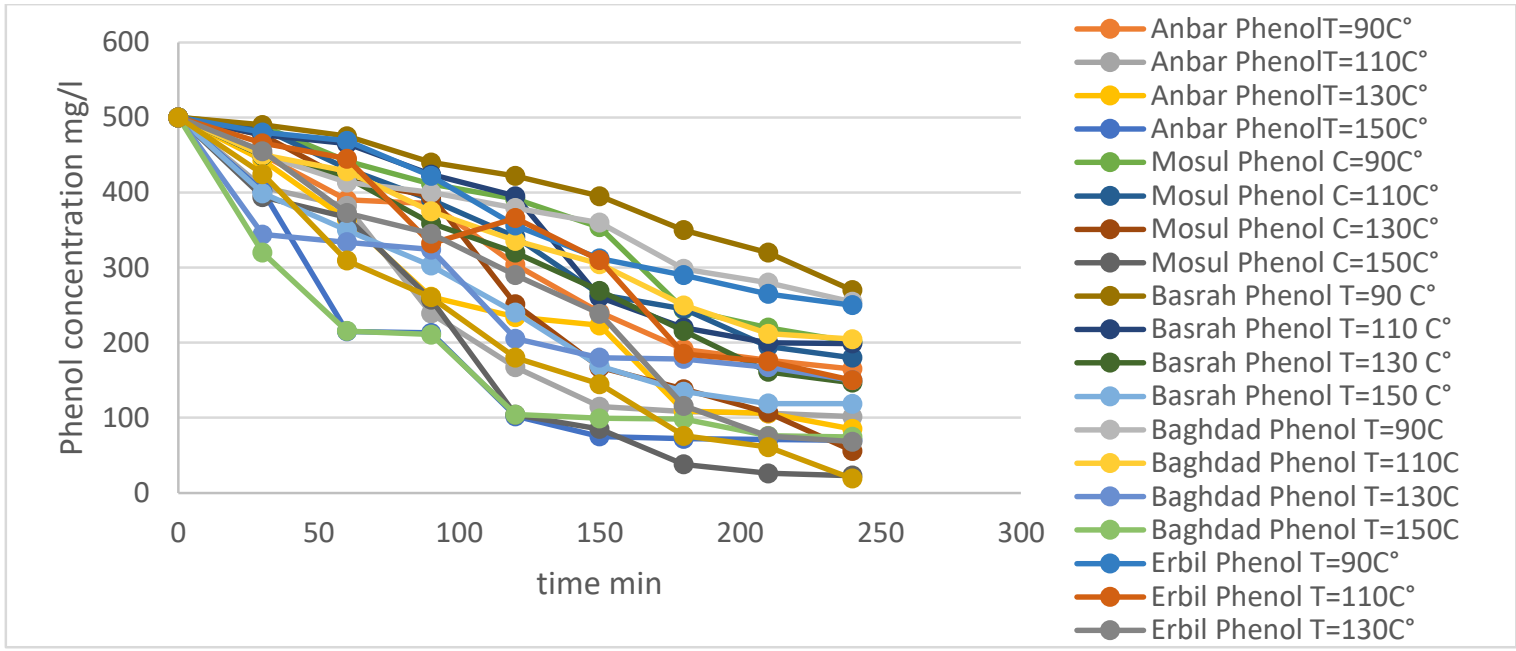

Fig (8): Phenol concentration during $4 \mathrm{hr}$ in catalyst loading $7 \mathrm{mg} / 1$, pressure $2.5 \mathrm{Mpa}, 500 \mathrm{mg} / 1$ phenol concentration.
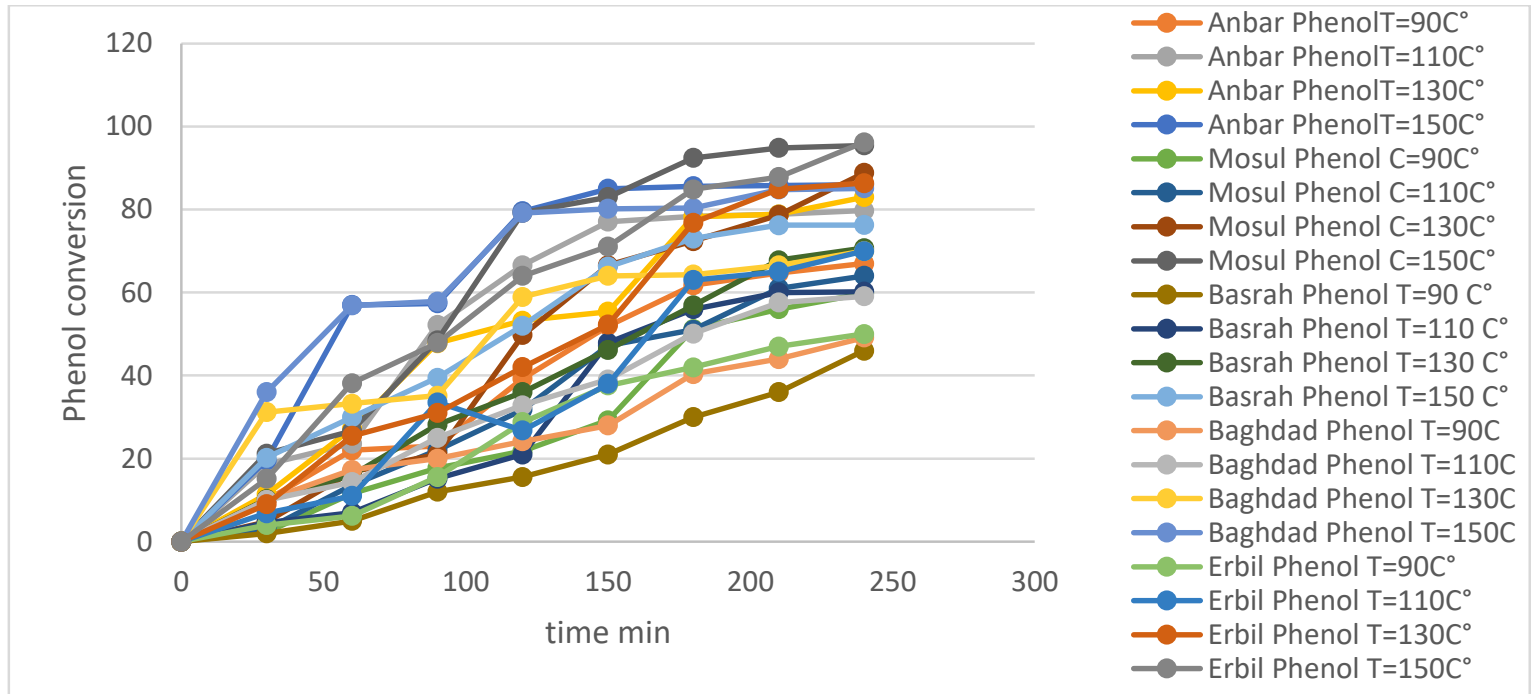

Fig (9): Phenol conversiontion during $4 \mathrm{hr}$ in catalyst loading $7 \mathrm{mg} / 1$, pressure $2.5 \mathrm{Mpa}, 500 \mathrm{mg} / \mathrm{l}$ phenol concentration.

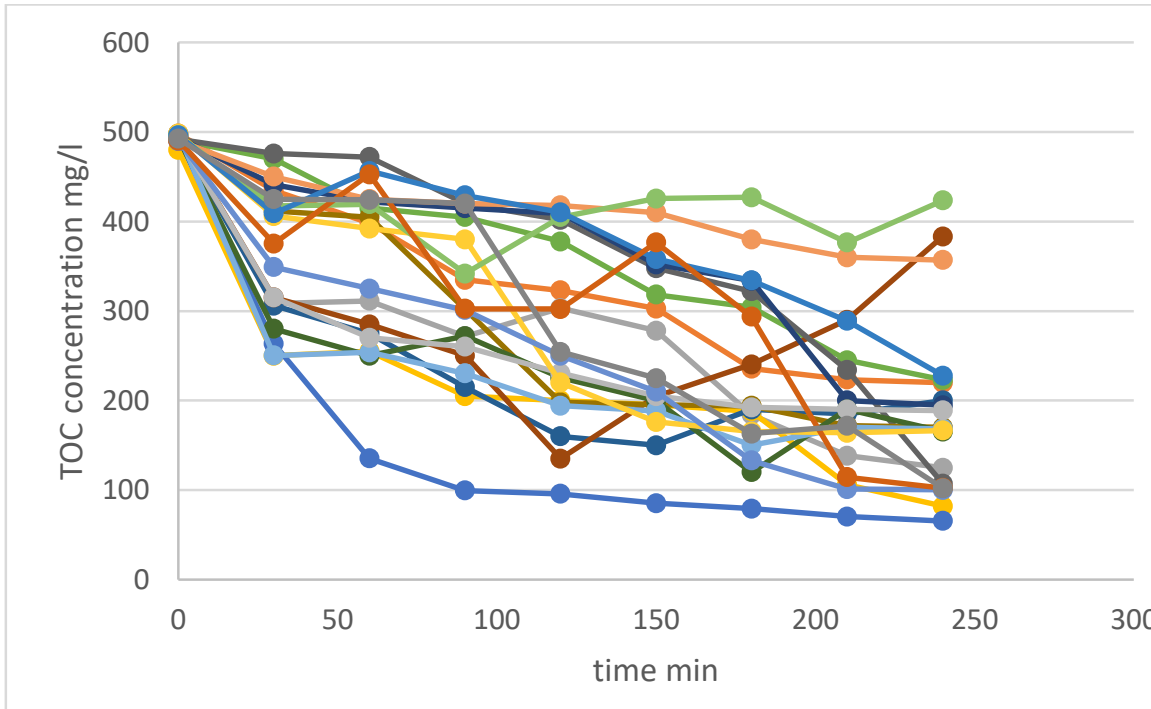
- Anbar TOC T=90 C
- Anbar TOC T $=110 \mathrm{C}^{\circ \circ}$
- Anbar TOC T $=130 \mathrm{C}^{\circ}$
-Anbar TOC T=150 $\mathrm{C}^{\circ}$
-Mosul TOC C=90C
-Mosul TOC C $=110 \mathrm{C}^{\circ}$
$\rightarrow$ Mosul TOC C $=130 \mathrm{C}^{\circ}$
-Mosul TOC C $=150 \mathrm{C}^{\circ}$
- Basrah TOC T $=90 \mathrm{C}^{\circ}$
-Basrah TOC T=110 C
$\longrightarrow$ Basrah TOC T $=130 \mathrm{C}^{\circ}$
- Basrah TOC T=150 C
- Baghdad TOC T=90C
-Baghdad TOC T=110C
-Baghdad TOC T=130C
- Baghdad TOC T=150C
- Erbil TOC $T=90 C^{\circ}$
$\longrightarrow$ Erbil TOC T $=110 \mathrm{C}^{\circ}$
- Erbil TOC T=130C
$\longrightarrow$ Erbil TOC $\mathrm{T}=150 \mathrm{C}^{\circ}$

Fig (10): TOC concentration during $4 \mathrm{hr}$ in catalyst loading $7 \mathrm{mg} / 1$, pressure $2.5 \mathrm{Mpa}, 500 \mathrm{mg} / 1$ phenol concentration. 


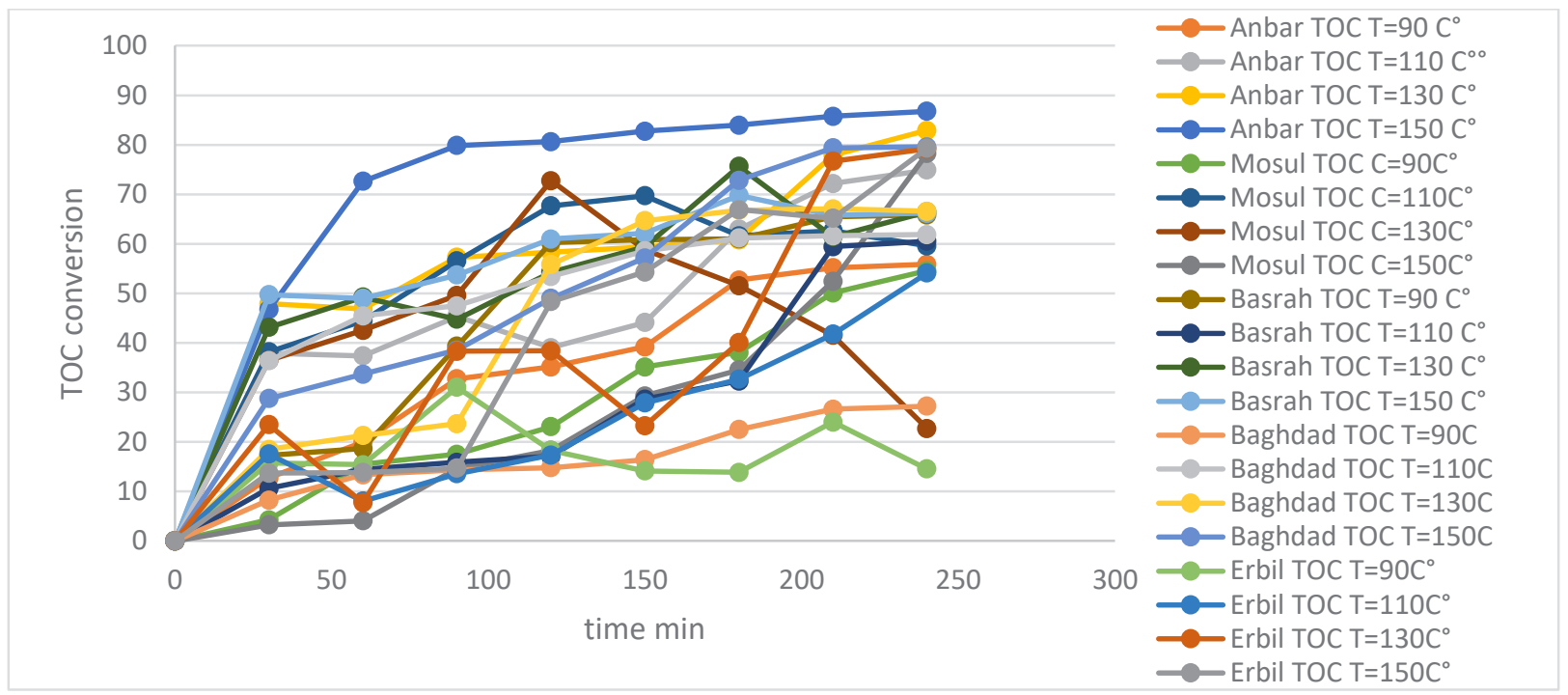

Fig (11): TOC concversion during $4 \mathrm{hr}$ in catalyst loading $7 \mathrm{mg} / \mathrm{l}$, pressure $2.5 \mathrm{Mpa}, 500 \mathrm{mg} / \mathrm{l}$ phenol concentration

During the experiment of catalyst activity, the stability is studied too, during the leaching, and blocking, in batch reactor, the atomic adsorption equipment was used for leaching test, observed the trace $\mathrm{Fe}$ in the liquid effluent samples that collected every $30 \mathrm{~min}$, low values result leaching so that these catalyst can be continuously operated. The result of leaching for Mosul an example is shown in Figure (12). While Figure (13) show the catalysts after used. The blocking is also measured by changing of surface area (BET). The surface area after blocking equal to (15.34, 23.65, 37.26, 79.04, $80.17 \mathrm{~m}^{2} / \mathrm{g}$ ) for (Basra- BaghdadErbil- Anbar- and Mosul) respectively. The higher blocking was shown in Basra and Baghdad equal to 75, $70 \%$ respectively, Erbil catalyst equal to $(63 \%)$, then Anbar catalyst (19.2\%), while AL-Mosul catalyst $(14.35 \%)$.

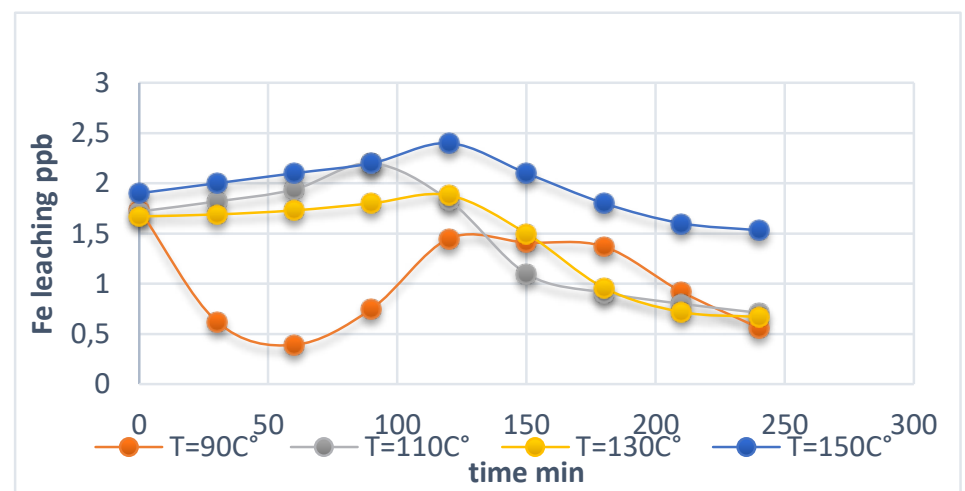

Fig. (12): Fe concentration with different temperature in batch reactor Mosul change temperature Fe leaching 
Anbar

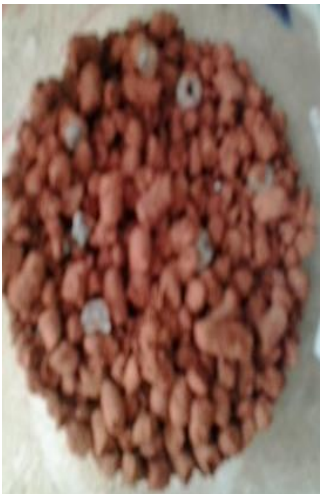

Mosul

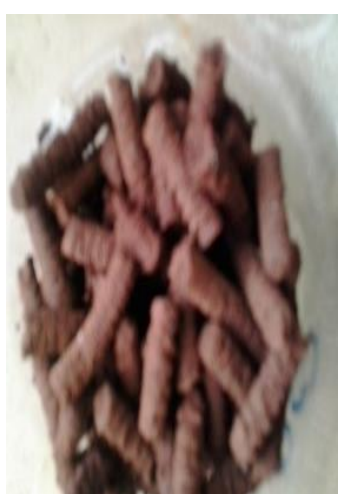

Erbil

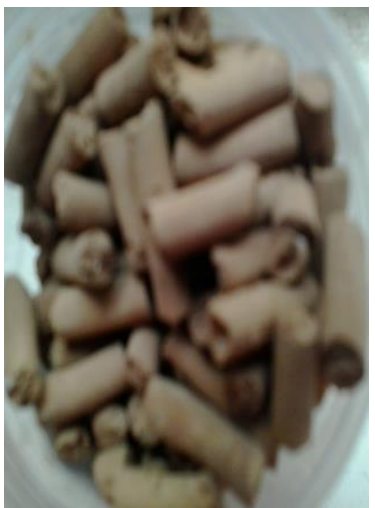

Baghdad

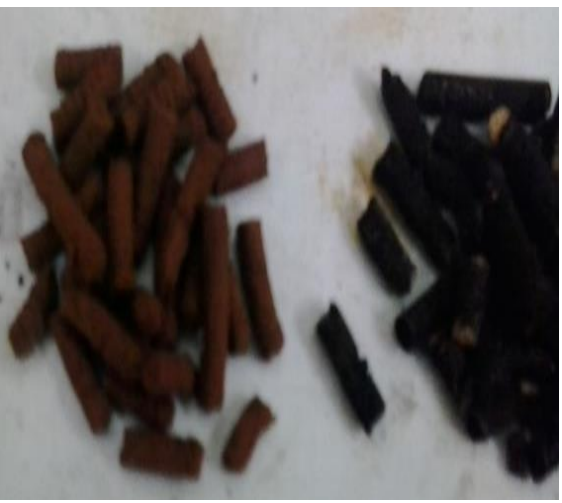

Fig. (13): Deactivation in all catalytic regions during phenol oxidation in batch reactor.

\section{Conclusions}

All the tests were conducted over extrudates that prepared $\mathrm{Fe}-\mathrm{Al}$ pillared Iraqi clay catalyst from five regions (Anbar- Erbil- Mosul- Basraand Baghdad) with dimension $(2 \times 8 \mathrm{~mm})$. All catalyst regions are stable and maintain activity during the experimental process, various characterization methods were employed for fresh and aged pillared clay catalysts previously used in batch reaction operation.

Surface analysis showed that the combined $\mathrm{Al}$ and $\mathrm{Fe}$ species were homogeneously dispersed

\section{References}

1- Nam, H.J, I.-S. S. W. Ham, and S. B. Hong, Catal. Today 68, 31 .Cross REF. (2001)

2- Figueras F. Catal. Rev.-Sci. Eng. 30, 457-499. (1988),

3- Molina, C.B. J.A. Casas, A.H. Pizarro, J.J. Rodriguez, Facultad de Ciencias, pp. 435474Top » Catalog » Books » Materials Science » Clay: Types, Properties and Uses Chapters Universidad Autónoma de Madrid, Madrid, Spain (2004).

4- Buker, R. A. and S.A.M. AL- Mallah, (2006) J. Educ. And Sci., 17(4), 42.Cited by Buker, R. A. J.Edu. \& Sci., 25 (1), 26-33. (2012)

5- Rodrigues M G F. Cerâmica, 49: 146(2003)

6- Murray H H. Applied clay mineralogy. 1 st edition, Copyright , Elsevier B.V., ISBN-13: 978-0-444-51701-2 (2007)

7- Oghenejoboh K M, Ohimor E O. European J Sci Res, 56(4): 445, (2011)

8- Wilson M. J. clay minerals 37, 7-25. (1999)

9- James, T .Richardson, book Library of congress cataloging in publication data .NEW YORK AND LONDON. (1989) between the silicate layers. During batch reactor deactivation appeared on Anbar clay, some time on Erbil and Mosul pillared cay, and the trace amount in (ppb) of Fe were detected in the liquid effluent, which means there is no leaching. The lowest blocking were shown in Mosul, and followed by Anbar, Erbil, Baghdad and Basra clay. From above it can be concluded that clay and silty clay (Mosul clay) are considered the best catalysts due to higher activity and stability through experiment of CWAO in batch reactor, with operation condition $150^{\circ} \mathrm{C}, 2.5 \mathrm{Mpa}, \mathrm{C}_{\text {cat }}$ equal to $7 \mathrm{mg} / 1$.

10- Naman S A, Maher K A, Ibrahim R P. Journal of Petroleum and Gas Exploration Research, 2(4): 80. (2012)

11- Wilson M. J. clay minerals 37, 7-25. (1999)

12- Stones, F.S. (1990) J. Mol. Cat., 59, 147. Cited by Buker, R. A., J.Edu. \& Sci., 25, (1). (2012)

13- Buker, R. A., J.Edu. \& Sci., 25 (1), 26-33. (2012)

14- Fajerwerg, K. H. Debellefontaine, Appl. Catal. B: Environ. 10 L229-L235. (1996)

15- Biomorgi, J., Pérez Zurita, M. J., Scott, C., de Navarro, C. U., Microsc Microanal 9, 434-435 (2003).

16- Suranjana Chaliha \& Krishna G Bhattacharyya. Journal of Chemical Technology vol 13, pp 499 504. (2006)

17- Guo, J., PhD .thesis -school of chemical Engineering, university of Washington. (2005).

18- Mishra, B. G.; Rao, G. R. Bull. Mater. Sci25, 155. (2002),

19- Sugunan S and N. K. Renuka. Ind. J. Chem., 41A, 304. (2002)

20- Poppe, L.J. Paskevich, V.F. Hathaway, J.C. and Blackwood, D.S., USGS U.S. Geological Survey Open-File Report 01-041. (2002)

21- International Center for Diffraction Data Joint Committee on 1990 "Powder Diffraction 
Standards, Powder Diffraction Data”, Swarthmore (PA).

22- Aibert, F. Cotton, John Wiley and Sons New York Inc. (1980)

23- Bankovic, P., A. Milutionovic., Nikolic, A. Rosic., N. Jovic - Jovicic, and Jovanovic, Journal of physical chemistry, vol 83 No. 9 PP 1485-1489. (2009)

24- Gregg S. J. and Sing K. S. W., 2nd ed., Academic: London. (1983),

25- Nicoleta Platon, ANA-Maria ROSU, Vasilica Alisa ARUS, Denisa Ileana Nistor, Ilie Siminiceanu, Journal of Engineering Studies and Research - Volume 19 No. 4, PP. 52-58. (2013)

26- Lastoskie, Christian, Keith E. Gubbins, and Nicholas Quirke. journal physical and chemical, 97, 4786-4796. (1993)
27- McNaught, A. D. and A. Wilkinson. Blackwell Scientific Publications, Oxford http://gold book.iupac.org (2006) created by M. Nic, J. Jirat, B. Kosata; updates compiled by A. Jenkins. ISBN 0-9678550-9-8. doi:10.1351/goldbook. Last update: 2014-02-24; version: 2.3.3. http://goldbook.iupac.org/C00876.html (1997).

28- Rob. J. Berger, E. Hugh Stitt*, Guy B. Marin, Freek Kapteijn, Jacob A. Moulijn, , EUOKEN Volume 5, no. 1, USA (2001).

29- Guo, J. and Al-Dahhan, M.H., Chem. Eng. Sci, 60, 735-746. (2005b) 